\title{
Dirofilariosis in the Americas: a more virulent Dirofilaria immitis?
}

\author{
Filipe Dantas-Torres ${ }^{1,2^{*}}$ and Domenico Otranto ${ }^{2}$
}

\begin{abstract}
Dirofilarioses are widespread diseases caused by filarioid nematodes (superfamily Filarioidea) of the genus Dirofilaria, which are transmitted by a plethora of mosquito species. The principal agent of canine dirofilariosis in the Americas is Dirofilaria immitis, which may also occasionally infest humans, resulting in pulmonary nodules that may be confounded with malignant lung tumours. Because human cases of dirofilariosis by D. immitis are relatively frequent in the Americas and rare in Europe and other eastern countries, where Dirofilaria repens is the main causative agent, the existence of a more virulent strain of D. immitis in the Americas has been speculated. Recently, a case of human ocular infestation by Dirofilaria sp. was diagnosed in Pará State, northern Brazil, where canine heartworm dirofilariosis is endemic. The nematode was shown to be morphologically and phylogenetically related to $D$. immitis but it was genetically distinct from reference sequences, including those of $D$. immitis infesting dogs in the same geographical area. This finding raised questions regarding the aetiology of human dirofilariosis in the Americas, since information on the genetic makeup of filarioids infesting dogs and humans is meagre. Further studies would be needed to better characterize filarioids infesting dogs, wild animals, and humans in the Americas and to assess the existence of a more virulent D. immitis strain in this continent. Finally, the competence of different culicid species/strains from Europe and the Americas as vectors of Dirofilaria species should be investigated. Such studies would help us to understand possible variations in transmission patterns and even to predict possible scenarios that may emerge in the future, with the introduction of non-endemic Dirofilaria species/strains in free areas through importation of infested animals, vectors, or both.
\end{abstract}

Keywords: Dirofilaria immitis, Americas, Genetics, Pathogenicity, Virulence, Zoonosis

\section{Introduction}

Dirofilariosis is a worldwide-distributed disease caused by nematodes of the genus Dirofilaria of the family Onchocercidae. These nematodes may infest wild and domestic mammals of several orders, such as Artiodactyla, Carnivora, Edentata, Lagomorpha, Perissodactyla, Primates, and Rodentia [1,2]. Most of the infested animals display no apparent clinical signs or laboratory abnormalities. However, some animals may develop clinical disease, which may range from benign, localized subcutaneous nodules to life-threatening, systemic conditions. For example, dogs infested by Dirofilaria immitis, also known as heartworm, can present with respiratory distress, epistaxis, haemoptysis, ascites, exercise intolerance, and

\footnotetext{
* Correspondence: filipe.vet@globo.com

'Department of Immunology, Aggeu Magalhães Research Centre, Oswaldo Cruz Foundation, Recife, Pernambuco 50670420, Brazil

${ }^{2}$ Department of Veterinary Medicine, Faculty of Veterinary Medicine, University of Bari, Valenzano, Bari 70010, Italy
}

anorexia [3,4]. Importantly, the treatment of canine dirofilariosis by $D$. immitis can be expensive and often associated with life-threatening complications, particularly in patients with moderate to severe heartworm disease [5].

Even if canine dirofilariosis is still widespread and highly prevalent worldwide, the availability of preventatives, improved diagnostic tools and different treatment options $[3,4]$ have greatly contributed in reducing the number of severe clinical cases, particularly those with a fatal outcome. Nonetheless, Dirofilaria infestations in dogs are still of major veterinary and public health concern, considering that canine and human dirofilariosis continue to be diagnosed in several tropical, subtropical and temperate regions of the world $[4,6,7]$.

Human cases of dirofilariosis have been reported worldwide. In the Old World, most cases refer to subcutaneous infestations by Dirofilaria repens, whereas

\section{() Biomed Central}

(C) 2013 Dantas-Torres and Otranto; licensee BioMed Central Ltd. This is an Open Access article distributed under the terms of the Creative Commons Attribution License (http://creativecommons.org/licenses/by/2.0), which permits unrestricted use, distribution, and reproduction in any medium, provided the original work is properly cited. 
in the New World pulmonary dirofilariosis by D. immitis predominates $[3,4]$. Nonetheless, it has been acknowledged that the aetiology of several human cases remains doubtful because the species identification is usually based on histological findings only. For example, a review of 28 cases of human dirofilariosis attributed to D. immitis or to a species other than $D$. repens in the Old World put in doubt the pathogenic role of the former species in humans in this region [8]. Indeed, even if the occurrence of human dirofilariosis by $D$. immitis in Europe has been ascertained $[9,10]$, the great majority of human pulmonary and subcutaneous infestations in the Old World are associated with $D$. repens [4]; except in Japan, where $D$. immitis prevails [11]. Although the zoonotic potential of different Dirofilaria species is well recognized, the control and prevention of Dirofilaria infestations in reservoir hosts is often neglected.

Information on the aetiology and, thus, eco-epidemiology of animal and human dirofilariosis in the Americas is fragmentary, particularly in South America. For instance, a recent human case of dirofilariosis from northern Brazil was attributed to a nematode morphologically and phylogenetically close to $D$. immitis but genetically distinct from reference sequences, including those of $D$. immitis infesting dogs in the same geographical area [12]. These findings raise interesting questions regarding the Dirofilaria species infesting wild and domestic animals in South America, as well on the aetiology of human pulmonary and subcutaneous dirofilariosis in the same region. Within this context, the present review focuses on some aspects related to the dirofilariosis and Dirofilaria parasites in the Americas, with an emphasis on South America, and lists future research needs on this neglected field of human parasitology.

\section{Review}

\section{Diversity of dirofilariae}

Dirofilariae are spirurid nematodes, which localize, with a few exceptions, in subcutaneous tissues of mammalian hosts (e.g., foxes, coyotes, wolves, dogs, sea lions, harbour seals, ferrets, horses, bears, wolverines, muskrats, raccoons, bobcats, cats, monkeys, and red pandas) and are transmitted predominately by mosquitoes [1,2,13-25]. The genus Dirofilaria consists of 27 apparently valid species (Table 1) and 15 species of questionable validity [1]. Moreover, 10 additional species of Dirofilaria have been replaced into other genera [1]. Potentially new species have also been proposed (e.g., "Candidatus Dirofilaria hongkongensis") [24], but considering the current number of doubtful species within this genus $[1,26]$ any description of a new species at this stage, mainly if supported only by genetic data, would be premature. In addition, a revision of the genus Dirofilaria based on robust morphological and genetic data would be needed before the description of any new species.

In the Americas, several Dirofilaria species have been reported from wild and domestic mammals. In Brazil alone, eight Dirofilaria species - i.e., D. acutiuscula, $D$. freitasi, D. incrassata, D. immitis, D. magalhaesi, $D$. repens, $D$. spectans, and $D$. striata - have been reported so far [2], even if the validity of at least one of those species (i.e., D. magalhaesi) has been questioned [1]. Moreover, the presence of $D$. repens in this country, and in the Americas as a whole, remains doubtful [4].

The presence of $D$. repens in the Americas has been first reported in a dog from São Paulo, south-eastern Brazil [26]. Recently, microfilariae resembling those of $D$. repens were detected in dogs from a semi-rural district near Santiago (Chile), but these microfilariae were larger and genetically distinct from $D$. repens [27]. In any case, these findings indicate that the diversity of Dirofilaria species in the Americas needs to be further investigated, also to determine whether cases of $D$. repens in dogs are being actually misdiagnosed as $D$. immitis based on the retrieval of blood circulating microfilariae.

\section{Mosquito vectors}

Given the fragmentary data on Dirofilaria species infesting wild and domestic animals in the Americas as well as the scant number of surveys on the mosquito species acting as potential vectors, the diversity of culicids transmitting Dirofilaria species in this region is currently underestimated. Indeed, little is known regarding the mosquito vectors of wildlife-associated Dirofilaria species, even considering that some of them (e.g., $D$. spectans, D. tenuis, and D. ursi) are of zoonotic concern [4]. On the other hand, several studies have succeeded in demonstrating the presence of infective third-stage larvae (L3) of $D$. immitis in naturally caught mosquitoes [28-31] or in proving experimentally the suitability of different mosquito species as proper intermediate hosts of this parasite [32-36].

Dirofilaria immitis can be transmitted by mosquitoes belonging to different genera, such as Aedes (Ae.), Anopheles $(A n$.$) , Culex (Cx.), and Ochlerotatus (Oc.). For instance,$ a study conducted in Rio de Janeiro State, south-eastern Brazil, using canine, feline and human baits, reported Oc. taeniorhynchus, Cx. quinquefasciatus, Oc. scapularis, $C x$. declarator, and $C x$. nigripalpus as the most likely vectors of $D$. immitis in this region [37]. Indeed, D. immitis developmental stages were found in Oc. scapularis, Oc. taeniorhynchus, Cx. quinquefasciatus, Cx. declarator, $C x$. saltanensis and Wyeomyia bourrouli, with L3 being found only in the first three species [28]. In another study conducted in Maranhão State, north-eastern Brazil, L3 were detected in Cx. quinquefasciatus [29]. Indeed, a subsequent experimental study demonstrated that $C x$. 
Table 1 The genus Dirofilaria

\begin{tabular}{|c|c|c|}
\hline Subgenus and species & Host (families) & Geographical distribution \\
\hline \multicolumn{3}{|l|}{ Subgenus Dirofilaria } \\
\hline D. ailure Ryjikov and Románova, 1961 & Procyonidae & China \\
\hline D. freitasi Machado de Mendonca, 1949 & Bradypodidae & Brazil \\
\hline D. immitis (Leidy, 1856) & Canidae, Felidae, Hominidae, and many others & Cosmopolitan \\
\hline D. lutrae Orihel, 1965 & Mustelidae & USA \\
\hline D. spectans Freitas and Lent, 1949 & Hominidae (single case), Mustelidae & Brazil \\
\hline \multicolumn{3}{|l|}{ Subgenus Nochtiella } \\
\hline D. acutiuscula (Molin, 1858) & Canidae, Caviidae, Felidae, Tayassuidae & South America, USA \\
\hline D. bonnie Vogel and Vogelsang, 1930 & Muridae & Java \\
\hline D. cancrivori Eberhard, 1978 & Procyonidae & Guyana \\
\hline D. corynodes (Linstow, 1899) & Cercopithecidae & Africa, Thailand \\
\hline D. genettae Baylis, 1928 & Felidae, Viverridae & Nigeria \\
\hline D. granulosa (Linstow, 1906) & Felidae & Africa, Asia \\
\hline D. incrassata (Molin, 1858) & Bradypodidae, Procyonidae & Brazil and Central America \\
\hline D. linstowi Dissanaike, 1972 & Cercopithecidae & Sri Lanka \\
\hline D. macacae Sandground, 1933 & Cercopithecidae & Indochina \\
\hline D. macrodemos Eberhard, 1978 & Bradypodidae & Guyana, Panama \\
\hline D. magnilarvata Price, 1959 & Cercopithecidae, Hominidae, Hylobatidae & Malaya \\
\hline D. minor Sandground, 1933 & Felidae & Vietnam \\
\hline D. pagumae Sandground, 1933 & Viverridae & Indochina \\
\hline D. panamensis Eberhard, 1978 & Bradypodidae & Panama \\
\hline D. repens Railliet and Henry, 1911 & Canidae, Felidae, Hominidae, Viverridae & Europe, Asia, Africa \\
\hline D. sachsi Shoho, 1974 & Bovidae & East Africa \\
\hline D. striata (Molin, 1858) & Canidae, Felidae, Hominidae (single case), Tayassuidae & Brazil, Venezuela, USA \\
\hline D. subdermata Mönnig, 1924 & Erethizontidae & North America, South Africa \\
\hline D. sudanensis (Linstow in Schipley 1902) & Felidae, Hyaenidae & Sudan \\
\hline D. tawila Khalil, 1932 & Cercopithecidae & Africa \\
\hline D. tenuis Chandler, 1942 & Hominidae, Procyonidae & North America \\
\hline D. ursi Yamaguti, 1941 & Felidae, Hominidae, Ursidae & Asia, North America \\
\hline
\end{tabular}

Checklist of valid species of Dirofilaria (adapted from Ref. [1]). Species of questionable validity are not listed.

quinquefasciatus supports the development of $D$. immitis to the L3 [34]. Similarly, non-infective stages of D. immitis were found in Cx. pipiens and Stegomyia aegypti and they have been regarded as putative vectors of this nematode in Argentina [38]. As a corollary, an experimental study conducted in Brazil confirmed the susceptibility of St. aegypti to D. immitis [36]. Meanwhile, studies conducted in the United States implicated several mosquito species as potential vectors of $D$. immitis, including St. aegypti, Stegomyia albopicta, Oc. canadensis, Jarnellius sierrensis, Oc. trivittatus, Aedimorphus vexans, An. punctipennis, An. quadrimaculatus, and Cx. quinquefasciatus [30,39-41]. Altogether, these studies underline that a plethora of mosquito species may act as vectors of $D$. immitis throughout the American continent, as it occurs in the Old World [42].
Worth mentioning, an interesting exception regarding Dirofilaria transmission is D. ursi, which infests American black bears (Ursus americanus) and is vectored by black flies (Simuliidae) [43].

\section{Transmission patterns}

The American continent is extremely variegated in terms of topography, hydrography and climate. As such, the transmission patterns of different vector-borne pathogens may vary widely throughout this vast land territory. Still, the knowledge on the transmission patterns of $D$. immitis and other filarial nematodes in the Americas remains fragmentary. Some mosquito species may present high specificity for city regions (e.g., urban, suburban, and rural) and landscape elements within these regions (e.g., forest, housing density) [44]. For instance, a study in 
Puerto Rico showed the association of St. aegypti with high-density housing in urban areas, of $C x$. quinquefasciatus with low-density housing in suburbs, and of Gymnometopa mediovittata and other native mosquitoes (Cx. antillummagnorum, Toxorhynchites portoricencis) with less disturbed habitats (forests, low-density housing) [44]. Therefore, the transmission of $D$. immitis may vary according to city region and landscape type. Indeed, studies indicate that the prevalence of heartworm infestation in dogs is usually higher in some coastal regions [45]. Because the development of mosquitoes is water and temperature dependent, wetlands (e.g., marsh, swamp, bog) and river valleys provide suitable environmental conditions for the vectors to develop, particularly in tropical and subtropical regions, where potential vectors of $D$. immitis are widespread and may be present throughout the entire year. For example, an entomological survey carried out in Rio de Janeiro, south-eastern Brazil revealed that St. aegypti and C. quinquefasciatus were present the year-round [46]. Accordingly, in these areas, the recommendation of preventatives (e.g., mosquito repellents and microfilaricides) becomes even more important towards the control of $D$. immitis infestation at the individual and population level.

In temperate regions, the presence of $D$. immitis vectors may be restricted to particular months of the year. For instance, mathematical models suggested that $D$. immitis transmission in Argentina is markedly seasonal (with peaks in January and February) and that no region of this country would support transmission throughout the year [47]. Undoubtedly, this sort of information may be valuable for veterinarians to recommend preventive strategies against $D$. immitis infestation in dogs, especially during high-risk months. The elaboration of optimized control strategies is particularly important in developing countries, where dog owners cannot always afford the costs of preventative chemoprophylactic measures.

\section{Canine and feline dirofilarioses}

In the Americas, there are reports of infestation by $D$. acutiuscula, D. immitis, D. repens, and D. striata in dogs $[1,2,6,45,48,49]$. Undoubtedly, $D$. immitis is the most important causative agent of canine dirofilariosis $[6,45]$, being found in most countries of the Americas, except Chile, French Guiana and Uruguay [4]. In the United States the infestation prevalence rate has been estimated to range from 1 to $12 \%$ [50]. In Central and South America, the prevalence rates may be much higher, reaching $42 \%$ in cities on the Gulf Coast of Mexico, $63.2 \%$ in the Caribbean (the Bahamas, Curaçao, Cuba, the Dominican Republic, and Puerto Rico), $45 \%$ in Brazil, and $74 \%$ in Argentina [4,6,38,45,51,52].

The reports of $D$. acutiuscula in a dog from Argentina [53], D. striata in a dog from the United States [48], and
D. repens in a dog from Brazil [26] and in dogs from Chile [27] are doubtful or need confirmation. Anyway, these findings raise some questions concerning the aetiology of canine dirofilariosis in the Americas as a whole. Indeed, a high nucleotide difference (5\%) was found between $12 \mathrm{~S}$ rDNA sequences generated from Chilean samples and a D. repens European sequence (GenBank accession number: AM779775), suggesting that the parasite found in Chile [27] may not be D. repens. Another study conducted in Marajó Island, northern Brazil, revealed some level of intra-specific difference in 5.8S and ITS2 regions [54]. In general, there is limited information on the genetic variability of filarioids infesting dogs worldwide. Certainly, further studies are urgently needed to obtain a more reliable picture regarding the species or genetic variants of dirofilariae circulating among dogs in the Americas.

In the Americas, feline dirofilariosis has been reported in the United States, Canada, Brazil, and Venezuela [4]. In a study carried out in northern Florida, necropsies performed on 630 adult cats revealed the presence of heartworms in $4.9 \%$ of them, with serological evidence of heartworm exposure in $17 \%$ of the tested population [55]. The highest rates of infection in cats parallel the levels of endemicity in dogs [4]. However, some studies in the United States and Brazil reported lower levels of exposure in cats living in areas were canine dirofilariosis is endemic [51], suggesting that the risk of infestation by D. immitis in cats may vary regardless of the prevalence of infestation in dogs from the same area.

\section{Human dirofilariosis in the Americas}

While most cases of human pulmonary dirofilariosis in the Americas have been attributed to D. immitis, other species may also infest and cause disease in humans in this region (Figure 1). For example, subcutaneous dirofilariosis in North America have been frequently attributed to D. tenuis and D. ursi (reviewed in Ref. [4]), which are primarily parasites of raccoons and bears, respectively [1]. Dirofilaria spectans, a parasite of otters in Brazil, has also been found in the digital artery of a human patient from Rio de Janeiro [56]. Similarly, $D$. striata (primarily found on wild felids) has been reported once in the orbit of a 6-year-old boy living in North Carolina [57]. Even considering that some species of Dirofilaria have been reported only once in humans, these case reports suggest that the number of potentially zoonotic dirofilariae in the American continent may be currently underestimated.

Little is known regarding the epidemiology and risk factors of human dirofilariosis in the Americas. The risk of infestation by some Dirofilaria species (e.g., D. tenuis) in humans is reputed to be higher in areas where there is a high incidence of these worms in their natural hosts 


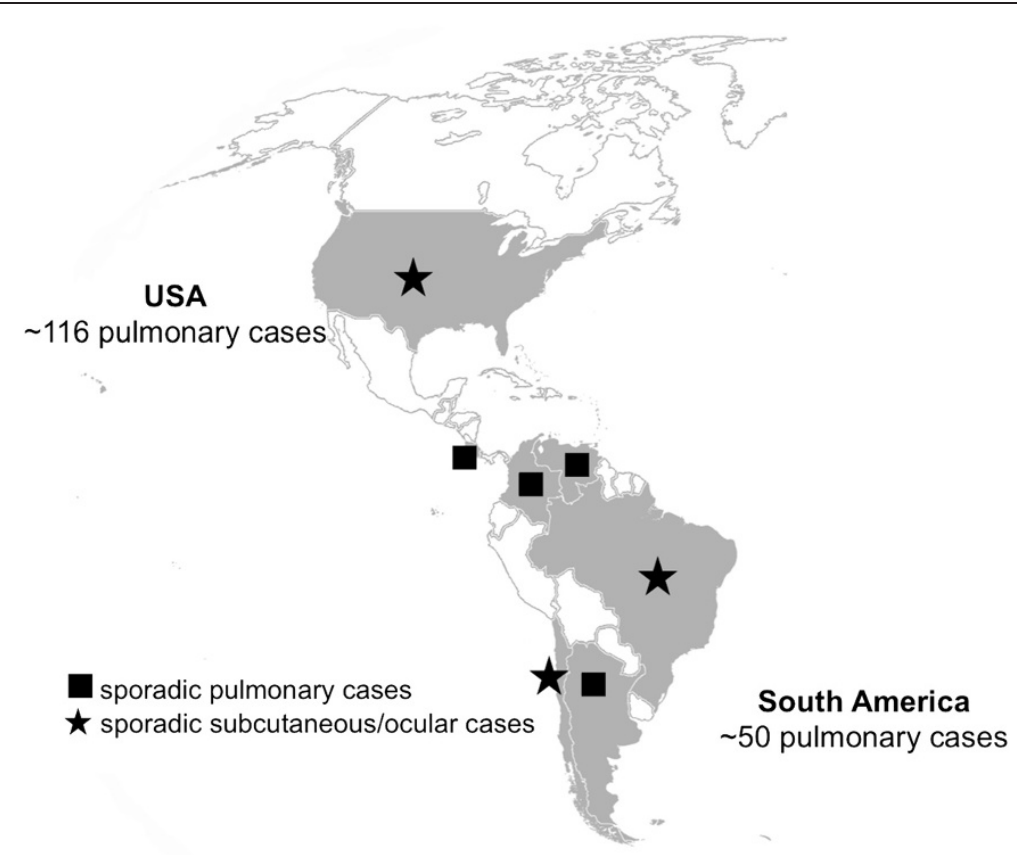

Figure 1 Human dirofilariosis in the Americas. Geographical distribution of human cases of dirofilariosis in the Americas (adapted from Ref. [4]). Countries in which Dirofilaria immitis cases predominate are in grey.

[58]. Importantly, following natural disasters, free-roaming dogs may represent a public health risk since they may increase transmission of some significant diseases such as rabies, leptospirosis, Chagas disease, leishmaniasis and even dirofilariosis. Indeed, natural catastrophic events may cause mass migration of people, and animals with rehabilitation of displaced people in temporary human settlements under unhygienic conditions or relocation of animals. Latin America is second in terms of number of natural disasters only to Asia [59], and thus represents an area at risk for spreading of Dirofilaria species as a consequence of the fact that these nematodes may adapt to new animal hosts and arthropod vectors. At some specific occasions, such as in the case of hurricane Katrina in the United States, dogs infected by D. immitis were relocated from the areas stricken by the hurricane (e.g., Louisiana) to other states of North America, resulting in the introduction of this filarioid into previously nonendemic areas [60].

Most human cases of dirofilariosis reported in the international literature refer to subcutaneous/ocular dirofilariosis cases caused by $D$. repens [4]. The great majority of these cases come from the Old World, where $D$. immitis and $D$. repens may co-infest the same reservoir hosts [7]. In the Americas, human pulmonary dirofilariosis predominates and it is primarily associated with $D$. immitis. For instance, over 100 cases have been detected in the United States, most of which coming from south-eastern regions where $D$. immitis infestation in dogs is highly prevalent $[4,50,61]$. Cases of human pulmonary dirofilariosis have also been reported in Brazil $[38,62,63]$ and, more rarely, in Costa Rica, Argentina, Venezuela, and Colombia [38,64-66]. Remarkably, approximately $70 \%$ of the cases reported in South America originated from south-eastern Brazil, particularly, from São Paulo city [67], one of the biggest medical poles in Latin America. Because the prevalence of $D$. immitis in dogs in São Paulo is low [68], the apparently high number of human pulmonary dirofilariosis from this state is probably due to the high standards of health care services provided. Indeed, there is no eco-epidemiological factor that could explain a higher risk of infestation in São Paulo city as compared with other Brazilian cities where canine dirofilariosis is endemic [49].

Subcutaneous/ocular dirofilariosis in the Americas have been attributed to different species, such as $D$. tenuis, $D$. ursi and D. immitis (a single case) in North America $[4,61]$. In addition, two interesting cases of subcutaneous and ocular dirofilarioses in human patients were reported from Chile [69] and Brazil [12], respectively. In the first case, the nematode was not identified to the species level, but a recent study reported the presence of microfilariae morphologically and phylogenetically related to $D$. repens in dogs from Chile [13]. This represents the first report of a Dirofilaria species in Chile and suggests a late introduction of this parasite in this country, which until recently was considered as a Dirofilaria-free area $[4,45,70]$. Further studies are advisable to better characterize this 
parasite. Similarly, a recent case of ocular dirofilariosis (Figure 2) was reported in a 16-year-old boy from Pará State, northern Brazil [12]. The parasite was morphologically and phylogenetically very similar to $D$. immitis. However, high nucleotide differences $(5 \%$ and $6 \%$ for $12 \mathrm{~S}$ rDNA and cytochrome c oxidase subunit 1, respectively) was found by comparing sequences from the nematode recovered from the patient's eye with sequences obtained from dogs living in the same area and/or from other countries available in GenBank [12]. This case report suggested that different strains or cryptic species of Dirofilaria, which is close to $D$. immitis, might be circulating in Brazil and in the western hemisphere as a whole.

\section{A more virulent ' $D$. immitis' in the Americas?}

A critical analysis of human dirofilariosis cases attributed to D. immitis in the Old World concluded that there is no proof demonstrating that Old World D. immitis plays a pathogenic role in humans [8]. Indeed, human pulmonary dirofilariosis in the Old World appears to be always associated with $D$. repens, even if $D$. immitis is more prevalent than $D$. repens in both dogs and vectors in some areas [42]. Based on this critical appraisal of human dirofilariosis in the Old World, two main hypotheses were proposed to explain this intriguing situation [8]. First, there could be different $D$. immits genotypes in the New and Old Worlds, with varying infective capacities for dogs and humans. Alternatively, some unidentified factor, probably related to the vector, could modify the infective capacity of the parasite to humans in the Old World. Although both hypotheses are plausible and deserve to be investigated more in-depth, there is no evidence indicating the existence of a more virulent $D$. immitis strain in the Americas.

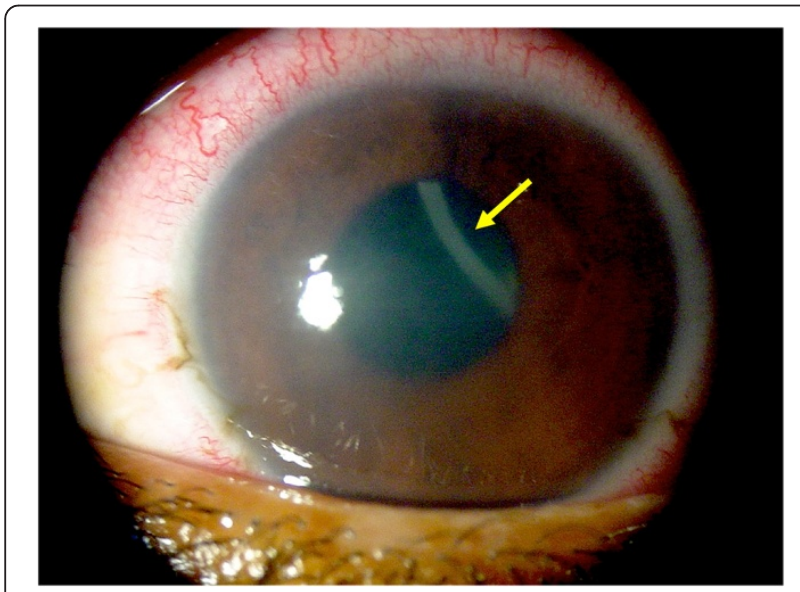

Figure 2 Human ocular dirofilariosis in Brazil. Corneal oedema and episcleral hyperaemia in the left eye of a 16-year-old boy from Brazil and a free-swimming filarioid (arrow) in the anterior chamber (adapted from Ref. [12]).
Even if some individuals can present with cough, chest pain, haemoptysis, and dyspnoea $[62,63,67,71]$, the majority of the cases of human pulmonary dirofilariosis reported in the literature refer to asymptomatic individuals that present a solitary, well-circumscribed, non-calcified peripheral subpleural pulmonary nodule ("coin lesion"), which are usually located in the lower lobes [62,72]. These nodules may mimic a malignant tumour and are often found by chance on chest radiograph and chest computerized tomography scans, which are usually requested for other reasons [62]. Importantly, in most cases, the identification of the parasite species is based on histological findings, which may not be adequate [8]. In fact, alterations in the parasite structures or the degeneration of worms inside nodules [4] may impair the identification of species.

\section{Conclusions}

Considering the usually benign nature of $D$. immitis infestation in human hosts, most cases of pulmonary dirofilariosis will likely remain without a definitive diagnosis. As a consequence, the actual number of pulmonary dirofilariosis in the Americas is likely to be grossly underestimated at present. Nonetheless, the existence of a more virulent strain of $D$. immitis in the Americas remains uncertain. So far, available data do not support this hypothesis, mainly considering that most human patients present no apparent clinical signs.

There are several lacunae in our knowledge regarding different aspects of animal and human dirofilarioses in the Americas. For example, bona fide information about the species of filarioids infesting dogs and humans in this region is meagre. Further studies are needed to better characterize filarioids circulating among different domestic and wild animals in the American continent. Certainly, the use of an integrated genetic (e.g., DNA barcoding using mitochondrial genes) and morphological approach could be beneficial for the identification of filarioids [73].

The high diversity of potential zoonotic dirofilariae in the Americas is undisputed, but information on the biology of most wildlife-associated Dirofilaria species is currently lacking. Similarly, scientific knowledge on the biology of Dirofilaria species infestation in humans is limited for obvious ethical reasons and several aspects of the host-parasite interactions (e.g., the proportion of inoculated larvae that develop, microfilariae migration routes) remain unknown. Certainly, studies on bacterial endosymbionts associated with Dirofilaria nematodes may provide further data on their biology and evolution [74], also considering that the presence or absence of Wolbachia pipientis in Dirofilaria species has been associated with the immunopathology of dirofilariosis $[4,74]$. In particular, dogs, cats, and humans may develop strong IgG response for the 
dominant Wolbachia surface protein and the participation of this bacterium in inflammatory processes occurring during dirofilariosis has been intensively investigated in recent years [4]. In addition, tetracyclines targeting the Wolbachia endosymbionts of filariae were useful in damaging or even killing D. immitis adult worms [75]. Therefore, the combination of doxycycline and ivermectin in long-lasting administration, in the place of melarsomine injections, succeeded in eliminating adults of D. immitis, eventually reducing the risk of thromboembolism [76]. A similar, therapeutic protocol, applied monthly, was shown to be effective for treating microfilariaemia in dogs affected by subcutaneous dirofilariosis by $D$. repens $[77,78]$.

The competence of different culicid species/strains in the Americas as vectors of Dirofilaria species should be better investigated. Such studies would help us to understand possible variations in transmission patterns and even to predict possible scenarios that may emerge in the future, with the introduction of non-endemic species/strains in free areas through importation of infested animals, vectors, or both. In this context, mathematical models and distribution maps are extremely important for predicting the presence/absence and abundance of mosquito vectors in different regions.

Finally, it is crucial to increase awareness among veterinary practitioners and medical physicians regarding the zoonotic significance of filarial nematodes of domestic and wild animals in the Americas. This is particularly important in remote areas, such as the Amazon region, where a different range of zoonotic, yet unknown filariae [79] is likely present.

\section{Competing interests}

The authors declare there are no conflicts of interest.

\section{Authors' contributions}

FD-T wrote the manuscript and DO reviewed critically it. Both authors approved the final version of the manuscript.

Received: 19 August 2013 Accepted: 26 September 2013 Published: 2 October 2013

\section{References}

1. Canestri Trotti G, Pampiglione S, Rivasi F: The species of the genus Dirofilaria, Railliet \& Henry, 1911. Parassitologia 1997, 39:369-374.

2. Vicente JJ, Rodrigues HO, Gomes DC, Pinto RM: Nematóides do Brasil. Parte V: nematóides de mamíferos. Rev Bras Zool 1997, 14(Suppl 1):1-452.

3. McCall JW, Genchi C, Kramer LH, Guerrero J, Venco L: Heartworm disease in animals and humans. Adv Parasitol 2008, 66:193-285.

4. Simón F, Siles-Lucas M, Morchón R, González-Miguel J, Mellado I, Carretón E, Montoya-Alonso JA: Human and animal dirofilariasis: the emergence of a zoonotic mosaic. Clin Microbiol Rev 2012, 25:507-544.

5. Hoch H, Strickland K: Canine and feline dirofilariasis: prophylaxis, treatment, and complications of treatment. Compend Contin Educ Vet 2008, 30:146-151.

6. Vezzani D, Carbajo AE, Fontanarrosa MF, Scodellaro CF, Basabe J, Cangiano G, Eiras DF: Epidemiology of canine heartworm in its southern distribution limit in South America: Risk factors, inter-annual trend and spatial patterns. Vet Parasitol 2011, 176:240-249.
7. Otranto D, Dantas-Torres F, Brianti E, Traversa D, Petrić D, Genchi C, Capelli $\mathrm{G}$ : Vector-borne helminths of dogs and humans in Europe. Parasit Vectors 2013, 6:16.

8. Pampiglione S, Rivasi F, Gustinelli A: Dirofilarial human cases in the Old World, attributed to Dirofilaria immitis: a critical analysis. Histopathology 2009, 54:192-204.

9. Avellis FO, Kramer LH, Mora P, Bartolino A, Benedetti P, Rivasi F: A case of human conjunctival dirofilariosis by Dirofilaria immitis in Italy. Vector Borne Zoonotic Dis 2011, 11:451-452.

10. Foissac M, Million M, Mary C, Dales JP, Souraud JB, Piarroux R, Parola P: Subcutaneous infection with Dirofilaria immitis nematode in human. France Emerg Infect Dis 2013, 19:171-172.

11. Miyoshi T, Tsubouchi H, Iwasaki A, Shiraishi T, Nabeshima K, Shirakusa T: Human pulmonary dirofilariasis: a case report and review of the recent Japanese literature. Respirology 2006, 11:343-347.

12. Otranto D, Diniz DG, Dantas Torres F, Casiraghi M, De Almeida IN, De Almeida LN, Dos Santos JN, Furtado AP, De Almeida Sobrinho EF, Bain O: Human intraocular filariasis caused by Dirofilaria sp. nematode, Brazil. Emerg Infect Dis 2011, 17:863-866.

13. Babero BB: Further studies on helminths of the opossum, Didelphis virginiana, with a description of a new species from this host. J Parasitol 1960, 46:445-463.

14. Orihel TC, Ash LR: Occurrence of Dirofilaria striata in the bobcat (Lynx rufus) in Louisiana with observations on its larval development. J Parasitol 1964, 50:590-591.

15. Orihel TC: Dirofilaria lutrae sp. n. (Nematoda:Filarioidea) from otters in the southeast United States. J Parasitol 1965, 51:409-413.

16. Eberhard ML: Dirofilaria macrodemos and D. panamensis spp. $\mathrm{n}$. (Nematoda: Filarioidea) from Central and South Americal sloths. J Parasitol 1978, 64:198-203.

17. Pung OJ, Davis PH, Richardson DJ: Filariae of raccoons from southeast Georgia. J Parasitol 1996, 82:849-851.

18. Segovia JM, Torres J, Miquel J, Llaneza L, Feliu C: Helminths in the wolf, Canis lupus, from north-western Spain. J Helminthol 2001, 75:183-192.

19. Noronha D, Vicente JJ, Pinto RM: A survey of new host records for nematodes from mammals deposited in the Helminthological Collection of the Oswaldo Cruz Institute (CHIOC). Rev Bras Zool 2002, 19:945-949.

20. Pence DB, Tewes ME, Laack LL: Helminths of the ocelot from southern Texas. J Wildl Dis 2003, 39:683-689.

21. Deem SL, Emmons LH: Exposure of free-ranging maned wolves (Chrysocyon brachyurus) to infectious and parasitic disease agents in the Noël Kempff Mercado National Park. Bolivia J Zoo Wildl Med 2005, 36:192-197.

22. Sato H, Suzuki K, Aoki M: Nematodes from raccoon dogs (Nyctereutes procyonoides viverrinus) introduced recently on Yakushima Island. Japan J Vet Med Sci 2006, 68:693-700.

23. Magi M, Calderini P, Gabrielli S, Dell'Omodarme M, Macchioni F, Prati MC, Cancrini G: Vulpes vulpes: a possible wild reservoir for zoonotic filariae. Vector Borne Zoonotic Dis 2008, 8:249-252.

24. To KK, Wong SS, Poon RW, Trendell-Smith NJ, Ngan AH, Lam JW, Tang TH, AhChong AK, Kan JC, Chan KH, Yuen KY: A novel Dirofilaria species causing human and canine infections in Hong Kong. J Clin Microbiol 2012, 50:3534-3541.

25. Lent H, Freitas JFT: Contribuição ao estudo do gênero Dirofilaria Railliet \& Henry, 1911. Mem Inst Oswaldo Cruz 1937, 32:37-54.

26. Lent H, Freitas JFT: Dirofilariose subcutânea dos cães no Brasil. Mem Inst Oswaldo Cruz 1937, 32:443-448.

27. López J, Valiente-Echeverría F, Carrasco M, Mercado R, Abarca K: Morphological and molecular identification of canine filariae in a semi-rural district of the metropolitan Region in Chile. Rev Chilena Infectol 2012, 29:248-289.

28. Labarthe N, Serrão ML, Melo YF, de Oliveira SJ, Lourenço-de-Oliveira R: Potential vectors of Dirofilaria immitis (Leidy, 1856) in Itacoatiara, oceanic region of Niterói municipality, state of Rio de Janeiro. Brazil Mem Inst Oswaldo Cruz 1998, 93:425-432.

29. Ahid SM, Lourenço-De-Oliveira R: Mosquitoes potential vectors of canine heartworm in the Northeast Region from Brazil. Rev Saude Publica 1999, 33:560-565.

30. Bowman DD, Atkins CE: Heartworm biology, treatment, and control. Vet Clin North Am Small Anim Pract 2009, 39:1127-1158.

31. Manrique-Saide P, Escobedo-Ortegón J, Bolio-González M, Sauri-Arceo C, Dzib-Florez S, Guillermo-May G, Ceh-Pavía E, Lenhart A: Incrimination of the mosquito, Aedes taeniorhynchus, as the primary vector of heartworm, 
Dirofilaria immitis, in coastal Yucatan. Mexico Med Vet Entomol 2010, 24:456-460.

32. Scoles GA, Dickson SL, Blackmore MS: Assessment of Aedes sierrensis as a vector of canine heartworm in Utah using a new technique for determining the infectivity rate. J Am Mosq Control Assoc 1993, 9:88-90.

33. Loftin KM, Byford RL, Loftin MJ, Craig ME: Potential mosquito vectors of Dirofilaria immitis in Bernalillo County, New Mexico. J Am Mosa Control Assoc 1995, 11:90-93.

34. Ahid SM, Vasconcelos PS, Lourenço-de-Oliviera R: Vector competence of Culex quinquefasciatus Say from different regions of Brazil to Dirofilaria immitis. Mem Inst Oswaldo Cruz 2000, 95:769-775.

35. Theis JH, Kovaltchouk JG, Fujioka KK, Saviskas B: Vector competence of two species of mosquitoes (Diptera: Culicidae) from southern California for Dirofilaria immitis (Filariidea: Onchocercidae). J Med Entomol 2000, 37:295-297.

36. Serrão ML, Labarthe $\mathrm{N}$, Lourenço-de-Oliveira R: Vectorial competence of Aedes aegypti (Linnaeus 1762) Rio de Janeiro strain, to Dirofilaria immitis (Leidy 1856). Mem Inst Oswaldo Cruz 2001, 96:593-598.

37. Labarthe N, Serrão ML, Melo YF, de Oliveira SJ, Lourenço-de-Oliveira R: Mosquito frequency and feeding habits in an enzootic canine dirofilariasis area in Niterói, state of Rio de Janeiro. Brazil Mem Inst Oswaldo Cruz 1998, 93:145-154.

38. Vezzani D, Eiras DF, Wisnivesky C: Dirofilariasis in Argentina: historical review and first report of Dirofilaria immitis in a natural mosquito population. Vet Parasitol 2006, 136:259-273.

39. Debboun M, Green TJ, Rueda LM, Hall RD: Relative abundance of tree hole-breeding mosquitoes in Boone County, Missouri, USA, with emphasis on the vector potential of Aedes triseriatus for canine heartworm, Dirofilaria immitis (Spirurida: Filariidae). J Am Mosq Control Assoc 2005, 21:274-278.

40. Licitra B, Chambers EW, Kelly R, Burkot TR: Detection of Dirofilaria immitis (Nematoda: Filarioidea) by polymerase chain reaction in Aedes albopictus, Anopheles punctipennis, and Anopheles crucians (Diptera: Culicidae) from Georgia. USA J Med Entomol 2010, 47:634-638.

41. Ledesma N, Harrington L: Mosquito vectors of dog heartworm in the United States: vector status and factors influencing transmission efficiency. Top Companion Anim Med 2011, 26:178-185.

42. Otranto D, Capelli G, Genchi C: Changing distribution patterns of canine vector borne diseases in Italy: leishmaniosis vs. dirofilariosis. Parasit Vectors 2009, 2(1):S2.

43. Michalski ML, Bain O, Fischer K, Fischer PU, Kumar S, Foster JM: Identification and phylogenetic analysis of Dirofilaria ursi (Nematoda: Filarioidea) from Wisconsin black bears (Ursus americanus) and its Wolbachia endosymbiont. J Parasitol 2010, 96:412-419.

44. Cox J, Grillet ME, Ramos OM, Amador M, Barrera R: Habitat segregation of dengue vectors along an urban environmental gradient. Am J Trop Med Hyg 2007, 76:820-826.

45. Labarthe N, Guerrero J: Epidemiology of heartworm: what is happening in South America and Mexico? Vet Parasitol 2005, 133:149-156.

46. Branco AS, Mendes De Almeida F, Faria MC, de Souza Dantas LM, Labarthe NV: Dirofilaria immitis (Leidy, 1856) in the neighborhood of a feline case: a study about the transmission. Rev Bras Parasitol Vet 2009, 18(1):14-18

47. Vezzani D, Carbajo AE: Spatial and temporal transmission risk of Dirofilaria immitis in Argentina. Int J Parasitol 2006, 36:1463-1472.

48. Pacheco G, Tulloch GS: Microfilariae of Dirofilaria striata in a dog. J Parasitol 1970, 56:248.

49. Dantas-Torres F: Canine vector-borne diseases in Brazil. Parasit Vectors 2008, 1:25

50. Lee AC, Montgomery SP, Theis JH, Blagburn BL, Eberhard ML: Public health issues concerning the widespread distribution of canine heartworm disease. Trends Parasitol 2010, 26:168-173.

51. Labarthe N, Ferreira AMR, Guerrero J, Newcomb K, Paes-de-Almeida E: Survey of Dirofilaria immitis (Leidy, 1856) in random source cats in metropolitan Rio de Janeiro, Brazil, with descriptions of lesions. Vet Parasitol 1997, 71:301-306.

52. Alves LC, de Almeida Silva LV, Faustino MA, McCall JW, Supakonderj P, Labarthe NW, Sanchez M, Caires O: Survey of canine heartworm in the city of Recife, Pernambuco. Brazil Mem Inst Oswaldo Cruz 1999, 94:587-590
53. Bacigalup J: Finding of Dirofilaria acutiuscula (Molin 1858) in a dog from Tigre (Province of Buenos Aires). Rev Soc Argent Biol 1950, 26:332-334.

54. Furtado AP, Do Carmo ES, Giese EG, Vallinoto AC, Lanfredi RM, Santos JN: Detection of dog filariasis in Marajo Island, Brazil by classical and molecular methods. Parasitol Res 2009, 105:1509-1515.

55. Levy JK, Snyder PS, Taveres LM, Hooks JL, Pegelow MJ, Slater MR, Hughes $\mathrm{KL}$, Salute ME: Prevalence and risk factors for heartworm infection in cats from northern Florida. J Am Anim Hosp Assoc 2003, 39:533-537.

56. Freitas JF, Mayall R: Fenómeno de Raynaud na mão esquerda, provocado por Dirofilaria spectans. Rev Bras Med 1953, 10:463-467.

57. Orihel TC, Isbey EK Jr: Dirofilaria striata infection in a North Carolina child. Am J Trop Med Hyg 1990, 42:124-126.

58. Weissman BW: Raccoon heartworm causing a facial mass. South Med J 1992, 85:845-846.

59. Toole MJ: Communicable diseases and disease control. In The Public Health Consequences of Disasters. Edited by Noji E. Oxford: Oxford University Press; 1997:79-98.

60. Levy JK, Edinboro CH, Glotfelty CS, Dingman PA, West AL, Kirkland Cady DK: Seroprevalence of Dirofilaria immitis, feline leukemia virus, and feline immunodeficiency virus infection among dogs and cats exported from the 2005 Gulf Coast hurricane disaster area. J Amer Vet Med Assoc 2007, 231:218-225.

61. Theis $\mathrm{JH}$ : Public health aspects of dirofilariasis in the United States. Vet Parasitol 2005, 133:157-180.

62. MilanezDe Campos JR, Barbas CS, Filomeno LT, Fernandez A, Minamoto $H_{\text {, }}$ Filho JV, Jatene FB: Human pulmonary dirofilariasis: analysis of 24 cases from São Paulo, Brazil. Chest 1997, 112:729-733.

63. Rodrigues-Silva R, Guerra RJ, de Almeida FB, Machado-Silva JR, de Paiva DD: Human pulmonary dirofilariasis at Rio de Janeiro, Brazil: a case report. Rev Soc Bras Med Trop 2004, 37:56-59.

64. Salfelder K, DavilaDe Arriaga A, Rujano J: Caso humano de dirofilariasis pulmonar. Acta Med Venez 1976, 23:87-90.

65. Brenes R, Beaver PC, Monge E, Zamora L: Pulmonary dirofilariasis in a Costa Rican man. Am J Trop Med Hyg 1985, 34:1142-1143.

66. Beaver $P$, Orihel T, Leonard G: Pulmonary dirofilariasis: restudy of worms reported gravid. Am J Trop Med Hyg 1990, 43:167-169.

67. Rodrigues-Silva R, Moura H, Dreyer G, Rey L: Human pulmonary dirofilariasis: a review. Rev Inst Med Trop Sao Paulo 1995, 37:523-530.

68. Souza NF, Larsson MHMA: Freqüência de dirofilariose canina (D. immitis) em algumas regiöes do Estado de Säo Paulo por meio da datecçäo de antígenos circulantes. Arq. Bras. Med. Vet. Zootec 2001, 53:321-325.

69. Pérez LC, Arce JD: Nódulos parasitarios cutáneos: estudio ultrasonográfico de tres casos poco frecuentes en la edad pediátrica. Rev Chil Radiol 2007, 13:163-168.

70. Alcaíno HA, Gorman TR, Puelma MC: Canine filariasis in Chile. Arch Med Vet $1984,16: 67-73$.

71. Cavallazzi R, Cavallazzi A, Souza I, Cardoso J: Dirofilariose pulmonar humana: relato de sete casos. J Pneumol. 2002, 28:100-102.

72. Ciferri F: Human pulmonary dirofilariasis in the United States: a critical review. Am J Trop Med Hyg 1982, 31:302-308.

73. Ferri E, Barbuto M, Bain O, Galimberti A, Uni S, Guerrero R, Ferté H, Bandi C, Martin C, Casiraghi M: Integrated taxonomy: traditional approach and DNA barcoding for the identification of filarioid worms and related parasites (Nematoda). Front Zool 2009, 6:1.

74. Casiraghi M, Bain O, Guerrero R, Martin C, Pocacqua V, Gardner SL, Franceschi A, Bandi C: Mapping the presence of Wolbachia pipientis on the phylogeny of filarial nematodes: evidence for symbiont loss during evolution. Int J Parasitol 2004, 34:191-203.

75. Kramer L, Grandi G, Leoni M, Passeri B, McCall J, Genchi C, Mortarino M, Bazzocchi C: Wolbachia and its influence on the pathology and immunology of Dirofilaria immitis infection. Vet Parasito/ 2008, 158:191-195.

76. Grandi G, Quintavalla C, Mavropoulou A, Genchi M, Gnudi G, Bertoni G, Kramer $L$ : A combination of doxycycline and ivermectin is adulticidal in dogs with naturally acquired heartworm disease (Dirofilaria immitis). Vet Parasitol 2010, 169:347-351. Erratum in: Vet. Parasitol. 2011, 177:196.

77. Sassnau R, Dyachenko V, Pantchev N, Stöckel F, Dittmar K, Daugschies A: Dirofilaria repens infestation in a sled dog kennel in the federal state of Brandenburg (Germany). Diagnosis and therapy of canine cutaneous dirofilariosis. Tierarztliche Praxis Ausgabe K Kleintiere Heimtiere 2009, 37:95-101.

78. Giannelli A, Ramos RA, Traversa D, Brianti E, Annoscia G, Bastelli F, Dantas-Torres F, Otranto D: Treatment of Dirofilaria repens 
microfilariaemia with a combination of doxycycline hyclate and ivermectin. Vet Parasitol. In press.

79. Bain O, Otranto D, Diniz DG, Dos Santos JN, De Oliveira NP, Frota De Almeida IN, Frota De Almeida RN, Frota De Almeida LN, Dantas-Torres F, De Almeida Sobrinho EF: Human intraocular filariasis caused by Pelecitus sp. nematode, Brazil. Emerg Infect Dis 2011, 17:867-869.

doi:10.1186/1756-3305-6-288

Cite this article as: Dantas-Torres and Otranto: Dirofilariosis in the Americas: a more virulent Dirofilaria immitis?. Parasites \& Vectors 2013 6:288.

\section{Submit your next manuscript to BioMed Central and take full advantage of:}

- Convenient online submission

- Thorough peer review

- No space constraints or color figure charges

- Immediate publication on acceptance

- Inclusion in PubMed, CAS, Scopus and Google Scholar

- Research which is freely available for redistribution 